\title{
REVIEW
}

\section{Criminal Law (Amendment) Act, 2013: Will it ensure women's safety in public spaces?}

Dr Rituparna Bhattacharyya ${ }^{+}$

\author{
Abstract \\ The horrific gang-rape and the subsequent murder of Nirbyaya (fearless) in December 2012, \\ impelled the Government of India to pass the Criminal Law (Amendment) Act, 2013. The key aim \\ of this article is to review this Act in the light of women's safety in public spaces. \\ Key words: Criminal Law (Amendment) Act, 2013, violence against women, women's safety, public \\ spaces, India
}

\footnotetext{
${ }^{\dagger}$ Alliance for Community Capacity Building in North East India, NE29 9JA, England [Email: rituparna.bhattacharyya@accb.org.uk] (c) 2013 Bhattacharyya. This is an Open Access article distributed under the terms of the Creative Commons Attribution License (http://creativecommons.org/licenses/by/2.0), which permits unrestricted use, distribution, and reproduction in any medium, provided the original work is properly cited.
} 


\section{Introduction}

Against the backdrop of the nation-wide outrage over the tragic Delhi gang-rape, Nirbhaya (Fearless) incident of December 16, 2012, propelled the Government of India (GOI) to drive the issue of violence against women (VAW) to the centre-stage of political discourse. Consequently, on December 22, 2012, GOI appointed a three-member judicial committee headed by the former Chief Justice of India, Justice J.S. Verma, who passed away on April 22, 2013, Justice Leila Seth and Gopal Subramanium requesting them to submit a report within 30 days. The key objective of the Commission was to review for possible amendments to the criminal law and suggest measures for faster trials and harsher penalties for vicious offences related to VAW. Taking further cognizance of the strident storm of public protests in general and a tribute to Nirbhaya (Fearless) in particular, on January 23, 2013, the commission submitted its recommendations by identifying 'lack of good governance' as the central cause of VAW. The commission goes on to criticise the government, the abysmal and old-fashioned police system alongside public apathy in tackling VAW, and thereby, recommends dramatic transformation in legislations. The recommendations are based on more than 70,000 suggestions received from stakeholders, social activists and public comprising eminent jurists, legal professionals, NGOs, women's groups and civil society through varied methods: emails, posts and fax. A 631-page report consisting of 14 chapters (excluding Introduction, Methodology and Conclusions and Recommendations) include recommendations on laws related to rape, sexual harassment, trafficking, child sexual abuse, medical examination of victims, police, electoral and educational reforms.

Based on some of the recommendations of the Justice Verma Committee (JVC) report, an antirape Ordinance was enacted and signed by the Honourable President of India, Mr Pranab Mukherjee on February 03, 2013. The Criminal Law (Amendment) Bill, 2013, passed in the
Parliament (Lok Sabha ${ }^{1}$ and Rajya Sabha ${ }^{2}$ respectively on March 19 and 21, 2013) replaced the promulgated Ordinance, which lapsed on April 04, 2013. However, as per the Gazette Notification New Delhi, Tuesday, April2, 2013, ${ }^{3}$ the word 'bill' has been replaced by the word 'Act'.

\section{Criminal Law (Amendment) Act, 2013}

Popularly, known as the Anti-rape Act, amends the Indian Penal Code (IPC), 1860, the Code of Criminal Procedure (CCP), 1973, the Indian Evidence Act (IEA), 1872 and the Protection of Children from Sexual Offences Act, (PCSO), 2012.In a way, the Act is a radical expression of the fifty-seventh session of the Commission on the Status of Women held at the United Nations Headquarters, New York, March 04-15, 2013 as both the interventions focus on VAW with particular emphasis on women's safety and security. Sadly, even after the declaration by the United Nations in 1993, that any type of VAW is a violation of human rights, incidents of VAW continue to be reported, which definitely is a tip of a very ugly iceberg. Yet, many more cases go unreported for various reasons (Viswanath and Mehrotra, 2007). The elusive goal of the commentary however, is to highlight those issues of the Act linked to women's safety and mobility in public spaces (see, Table 1).

\footnotetext{
${ }^{1}$ The house of people; the lower house of the Parliament of India.

${ }^{2}$ The council of states elected by the states' assemblies; the upper house of the Parliament of India.

${ }^{3}$ The Gazette of India, Department of Publication, Ministry of Urban Development, Government of India, http://egazette.nic.in/RecentUploads.aspx?Category=1 (accessed April 16, 2013)
} 
Bhattacharyya. Space and Culture, India 2013, 1:1

Table 1: Comparison between the Existing Laws, JVC Report recommendation and Criminal Law (Amendment) Act, 2013

\begin{tabular}{|c|c|c|c|c|}
\hline Offence/Issue & Definition & Existing Laws & $\begin{array}{l}\text { JVC report } \\
\text { recommendation }\end{array}$ & $\begin{array}{l}\text { Criminal Law } \\
\text { (Amendment) Act, } 2013\end{array}$ \\
\hline $\begin{array}{l}\text { Disobedience of law } \\
\text { by a public servant }\end{array}$ & $\begin{array}{l}\text { Failure to record } \\
\text { information in sexual } \\
\text { offences cases; } \\
\text { knowingly disobeying } \\
\text { laws on investigation }\end{array}$ & $\begin{array}{lr}\text { No } & \text { specific } \\
\text { provision, } & \text { IPC, } \\
1860 & \end{array}$ & $\begin{array}{l}\text { Failure of a public } \\
\text { servant to record } \\
\text { information in } \\
\text { relation to sexual } \\
\text { offences should be } \\
\text { specifically penalised } \\
\text { under the Bill. }\end{array}$ & $\begin{array}{l}\text { Punishable with } \\
\text { rigorous imprisonment } \\
\text { for six months to } 2 \\
\text { years and fine. }\end{array}$ \\
\hline $\begin{array}{l}\text { Rape resulting in } \\
\text { death or vegetative } \\
\text { state }\end{array}$ & $\begin{array}{l}\text { Causing death or } \\
\text { persistent vegetative } \\
\text { state when } \\
\text { committing rape. }\end{array}$ & $\begin{array}{l}\text { Rape and murder } \\
\text { dealt with as two } \\
\text { separate offences. } \\
\text { Rape: } 7 \text { years to } \\
\text { life imprisonment, } \\
\text { Murder: } \\
\text { imprisonment for } \\
\text { life or death, IPC, } \\
1860 \text {. }\end{array}$ & $\begin{array}{l}\text { Punishment } 20 \text { years } \\
\text { up to life } \\
\text { imprisonment. } \\
\text { In case of gang rape } \\
\text { resulting in death or } \\
\text { persistent vegetative } \\
\text { state punishment } \\
\text { should extend to life } \\
\text { imprisonment }\end{array}$ & $\begin{array}{l}\text { Specific offence. } \\
\text { Punishment } 20 \text { years to } \\
\text { life imprisonment } \\
\text { (rigorous imprisonment) } \\
\text { or death. }\end{array}$ \\
\hline $\begin{array}{l}\text { Punishment for } \\
\text { gang rape }\end{array}$ & $\begin{array}{l}\text { Where a person is } \\
\text { raped by one or } \\
\text { more in a group of } \\
\text { persons acting in } \\
\text { furtherance of a } \\
\text { common intention, } \\
\text { each of these } \\
\text { persons shall be } \\
\text { deemed to have } \\
\text { committed the } \\
\text { offence gang rape, } \\
\text { of their } \\
\text { regardless of ther gender }\end{array}$ & $\begin{array}{l}10 \text { years to life } \\
\text { imprisonment and } \\
\text { fine, IPC, } 1860\end{array}$ & $\begin{array}{l}\text { Imprisonment for life } \\
\text { shall mean } \\
\text { imprisonment for } \\
\text { the rest of that } \\
\text { person's natural life. }\end{array}$ & $\begin{array}{l}20 \text { years to life } \\
\text { imprisonment (rigorous } \\
\text { imprisonment) and fine } \\
\text { payable to the victim, } \\
\text { that is reasonable to } \\
\text { meet medical expenses. }\end{array}$ \\
\hline $\begin{array}{l}\text { Rape by armed } \\
\text { personnel }\end{array}$ & $\begin{array}{l}\text { "Armed forces" } \\
\text { means the naval, } \\
\text { military and air } \\
\text { forces and includes } \\
\text { any member of the } \\
\text { Armed Forces } \\
\text { constituted under } \\
\text { any law for the time } \\
\text { being including } \\
\text { in force, inamilitary } \\
\text { the and } \\
\text { forces and any } \\
\text { auxiliary forces that } \\
\text { are under } \\
\text { the control of the } \\
\text { Central Government } \\
\text { or the State } \\
\text { Government }\end{array}$ & $\begin{array}{lr}\text { No } & \text { specific } \\
\text { provision. } & \text { Public } \\
\text { servant } & \text { includes } \\
\text { armed personnel. } \\
\text { Punishment: } 10 \\
\text { years to } \quad \text { life } \\
\text { imprisonment and } \\
\text { fine, IPC, } 1860\end{array}$ & $\begin{array}{l}\text { Specifically penalises } \\
\text { rape by armed } \\
\text { personnel within the } \\
\text { area they are } \\
\text { deployed in. Armed } \\
\text { personnel should be } \\
\text { penalised with } \\
\text { imprisonment for } 7 \\
\text { to } 10 \text { years if they } \\
\text { knew that sexual } \\
\text { offences were being } \\
\text { committed by their } \\
\text { subordinates. } \\
\text { The requirement for } \\
\text { sanction to } \\
\text { prosecute armed } \\
\text { personnel should be } \\
\text { removed in relation } \\
\text { to sexual offences. }\end{array}$ & $\begin{array}{l}\text { Specific offence. Shall } \\
\text { be punished with } \\
\text { rigorous imprisonment } \\
\text { of either description for } \\
\text { a term } \\
\text { which shall not be less } \\
\text { than seven years, but } \\
\text { which may extend to } \\
\text { imprisonment for } \\
\text { life }\end{array}$ \\
\hline $\begin{array}{l}\text { Responsibility of } \\
\text { Hospital }\end{array}$ & $\begin{array}{l}\text { Failure of hospitals } \\
\text { and doctors to } \\
\text { provide medical } \\
\text { treatment to victims }\end{array}$ & 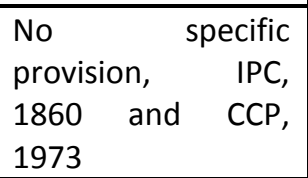 & $\begin{array}{l}\text { The victim must be } \\
\text { taken to the nearest } \\
\text { hospital. Medical } \\
\text { examination report }\end{array}$ & $\begin{array}{l}\text { Punishable with } 1 \text { year } \\
\text { and/or fine. } \\
\text { In cases of acid attacks } \\
\text { or rape, all hospitals }\end{array}$ \\
\hline
\end{tabular}




\begin{tabular}{|c|c|c|c|c|}
\hline & of sexual offences. & & $\begin{array}{l}\text { must be prepared, } \\
\text { preferably } \\
\text { immediately after } \\
\text { the examination, but } \\
\text { most } \\
\text { certainly on the } \\
\text { same date as the } \\
\text { examination and } \\
\text { must be forwarded } \\
\text { to the investigating } \\
\text { agency } \\
\text { forth } \\
\text { immediately. } \\
\text { All hospitals should } \\
\text { co-operate with the } \\
\text { police the } \\
\text { and preserve the } \\
\text { samples likely to } \\
\text { putrefy in their } \\
\text { pathological facility } \\
\text { till such time the } \\
\text { police are able } \\
\text { to complete their } \\
\text { paper work for } \\
\text { despatch to forensic } \\
\text { lab test including } \\
\text { DNA. }\end{array}$ & $\begin{array}{l}\text { (public and private) are } \\
\text { required to provide free } \\
\text { medical treatment to } \\
\text { the victim and } \\
\text { immediately inform the } \\
\text { police. }\end{array}$ \\
\hline Acid Attacks & $\begin{array}{l}\text { Throwing of } \\
\text { acid on women for a } \\
\text { multitude of reasons, } \\
\text { including alleged } \\
\text { adultery, turning } \\
\text { down } \\
\text { advances from men, } \\
\text { and also as a form of } \\
\text { domestic violence. } \\
\text { Causing permanent } \\
\text { or partial deformity } \\
\text { or burns on any } \\
\text { person by throwing } \\
\text { or administering } \\
\text { acid. }\end{array}$ & $\begin{array}{l}\text { No specific } \\
\text { provision. Covered } \\
\text { under grievous } \\
\text { hurt. Punishment: } \\
\text { up to } 7 \text { years } \\
\text { imprisonment, IPC, } \\
1860 .\end{array}$ & $\begin{array}{l}\text { Whoever attempts } \\
\text { to throw acid or } \\
\text { corrosive or any } \\
\text { burning substances } \\
\text { on any person, or } \\
\text { attempts to } \\
\text { administer } \\
\text { acid to any person, } \\
\text { or attempts to use } \\
\text { any other means to } \\
\text { achieve the purpose } \\
\text { of causing } \\
\text { permanent or partial } \\
\text { damage to any part } \\
\text { or parts of the body } \\
\text { of a person, shall be } \\
\text { punished with } \\
\text { rigorous the } \\
\text { imprisonment for a } \\
\text { term which shall not } \\
\text { be less than five } \\
\text { years to to } \\
\text { but which may } \\
\text { extend to seven } \\
\text { years, and shall also } \\
\text { be liable to pay } \\
\text { compensation to the } \\
\text { victim adequate to } \\
\text { meet at least the } \\
\text { medical expenses } \\
\text { incurred by the }\end{array}$ & \begin{tabular}{lr} 
Specific offence. & \multicolumn{2}{r}{ or } \\
Punishable with 10 \\
years or \\
imprisonment life \\
reasonable fine amount \\
to meet medical \\
expenses.
\end{tabular} \\
\hline
\end{tabular}




\begin{tabular}{|c|c|c|c|c|}
\hline & & & victim. & \\
\hline $\begin{array}{l}\text { Punishment for } \\
\text { repeat offenders }\end{array}$ & $\begin{array}{l}\text { Punishments for } \\
\text { persons previously } \\
\text { convicted of an } \\
\text { offence of rape, } \\
\text { custodial rape, and } \\
\text { gang rape. }\end{array}$ & $\begin{array}{lr}\text { No } & \text { specific } \\
\text { provision, } & \text { IPC, } \\
1860 & \end{array}$ & $\begin{array}{l}\text { Shall be punished } \\
\text { with imprisonment } \\
\text { for life, which means } \\
\text { imprisonment for } \\
\text { the rest of that } \\
\text { person's natural } \\
\text { life. }\end{array}$ & $\begin{array}{l}\text { Specific offence. Life } \\
\text { imprisonment (rigorous } \\
\text { imprisonment) } \\
\text { death. }\end{array}$ \\
\hline Age of Consent & $\begin{array}{l}\text { Legal age at which a } \\
\text { person is considered } \\
\text { competent to give } \\
\text { sexual consent } \\
\text { (sexual intercourse) }\end{array}$ & $\begin{array}{l}\text { Specific provision, } \\
\text { since the } 1983 \\
\text { amendments in the } \\
\text { rape law in the IPC, } \\
1860\end{array}$ & 16 years & 18 years \\
\hline Touching & $\begin{array}{l}\text { Physical contact } \\
\text { involving unwelcome } \\
\text { and explicit sexual } \\
\text { overtures. }\end{array}$ & $\begin{array}{l}\text { Outraging a } \\
\text { woman's modesty. } \\
\text { Punishment: } \\
\text { imprisonment for } \\
\text { maximum } 2 \text { years } \\
\text { and fine, IPC, } 1860\end{array}$ & $\begin{array}{l}\text { Existing provisions of } \\
\text { the IPC should be } \\
\text { deleted. Intentional } \\
\text { touching of a sexual } \\
\text { nature, without the } \\
\text { person's consent } \\
\text { should be penalised } \\
\text { with } 5 \text { years rigorous } \\
\text { imprisonment. }\end{array}$ & $\begin{array}{l}\text { Outraging a woman's } \\
\text { modesty: } 1 \text { to } 5 \text { years } \\
\text { imprisonment and fine. } \\
\text { Physical contact } \\
\text { involving unwelcome } \\
\text { and explicit sexual } \\
\text { overtures: up to } 3 \text { years } \\
\text { imprisonment and/or } \\
\text { fine. }\end{array}$ \\
\hline Stalking & $\begin{array}{l}\text { Following a woman, } \\
\text { attempting to foster } \\
\text { personal interaction } \\
\text { despite indication of } \\
\text { victim's disinterest, } \\
\text { spying, monitoring } \\
\text { electronic } \\
\text { communications }\end{array}$ & $\begin{array}{ll}\text { No } & \text { specific } \\
\text { provision. } & \end{array}$ & $\begin{array}{l}\text { Whoever commits } \\
\text { the offence shall be } \\
\text { punished with } \\
\text { imprisonment of } \\
\text { either description for } \\
\text { a term which shall } \\
\text { not be less than one } \\
\text { year but which may } \\
\text { extend to three } \\
\text { years, and shall also } \\
\text { be liable to fine. }\end{array}$ & $\begin{array}{l}\text { Specific offence. 1st } \\
\text { offence punishable with } \\
1 \text { to } 3 \text { years } \\
\text { imprisonment } \\
\text { (Bailable). 2nd offence } \\
\text { punishable with up to } 5 \\
\text { years imprisonment } \\
\text { (Non-bailable). }\end{array}$ \\
\hline $\begin{array}{l}\text { Sexually coloured } \\
\text { remarks/Use of } \\
\text { words or gestures to } \\
\text { insult a woman's } \\
\text { modesty }\end{array}$ & $\begin{array}{l}\text { Making of sexually } \\
\text { coloured remarks by } \\
\text { a man. }\end{array}$ & $\begin{array}{l}\text { No specific } \\
\text { provision for this } \\
\text { offence. Verbally } \\
\text { assaulting a } \\
\text { woman's modesty } \\
\text { is punishable with } \\
\text { one year } \\
\text { imprisonment } \\
\text { and/or fine, IPC, } \\
1860 \text {. }\end{array}$ & $\begin{array}{l}\text { Use of words or } \\
\text { gestures towards a } \\
\text { person, or in his } \\
\text { presence, which } \\
\text { creater an } \\
\text { unwelcome threat of } \\
\text { a sexual nature, } \\
\text { should be punishable } \\
\text { with imprisonment } \\
\text { for one year and/or } \\
\text { fine. }\end{array}$ & $\begin{array}{l}\text { Specific offence. } \\
\text { Punishable with } \\
\text { imprisonment for up to } \\
\text { one year and/or fine. } \\
\text { Non Bailable }\end{array}$ \\
\hline $\begin{array}{l}\text { Demand for Sexual } \\
\text { Flavour }\end{array}$ & $\begin{array}{l}\text { Demand or request } \\
\text { by a man for sexual } \\
\text { favours. }\end{array}$ & $\begin{array}{l}\text { No specific } \\
\text { provision for this } \\
\text { offence. Verbally } \\
\text { assaulting } \\
\text { woman's modesty } \\
\text { is punishable with } \\
\text { one year } \\
\text { imprisonment } \\
\text { and/or fine, IPC, } \\
1860\end{array}$ & $\begin{array}{l}\text { Those who demand } \\
\text { or request for sexual } \\
\text { favour should be } \\
\text { punishable with } \\
\text { imprisonment for } \\
\text { one year and/or fine. }\end{array}$ & 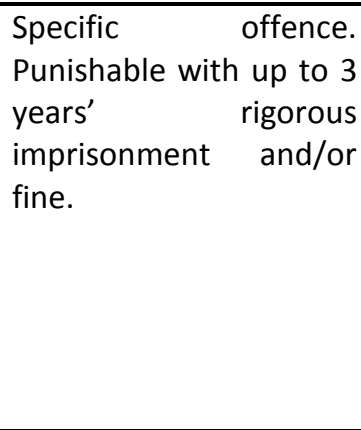 \\
\hline $\begin{array}{l}\text { Assault to disrobe a } \\
\text { woman }\end{array}$ & $\begin{array}{l}\text { Forcing a woman to } \\
\text { undress and lie in } \\
\text { naked condition. }\end{array}$ & $\begin{array}{l}\text { No specific offence. } \\
\text { Outraging a } \\
\text { woman's modesty } \\
\text { is punishable with }\end{array}$ & $\begin{array}{l}\text { Whoever assaults or } \\
\text { uses criminal force to } \\
\text { any woman or abets } \\
\text { such act with the }\end{array}$ & $\begin{array}{l}\text { Specific offence. } \\
\text { Punishable with } 3 \text { to } 7 \\
\text { years imprisonment and } \\
\text { fine. }\end{array}$ \\
\hline
\end{tabular}




\begin{tabular}{|c|c|c|c|c|}
\hline & & $\begin{array}{l}\text { imprisonment for } \\
\text { maximum } 2 \text { years } \\
\text { and fine, IPC, } 1860\end{array}$ & $\begin{array}{l}\text { intention of } \\
\text { disrobing or } \\
\text { compelling her to be } \\
\text { naked in any public } \\
\text { place, shall be } \\
\text { punished with } \\
\text { imprisonment of } \\
\text { either description for } \\
\text { a term which shall } \\
\text { not be less than } \\
\text { three years but } \\
\text { which may extend to } \\
\text { seven years and shall } \\
\text { be liable to fine. }\end{array}$ & \\
\hline Voyeurism & $\begin{array}{l}\text { Watching a woman } \\
\text { when she is engaging } \\
\text { in a private act } \\
\text { including sexual acts, } \\
\text { use of lavatory, or } \\
\text { when private parts } \\
\text { are exposed. }\end{array}$ & $\begin{array}{l}\text { No specific offence, } \\
\text { IPC, } 1860 \text {. } \\
\text { Information } \\
\text { Technology Act, } \\
2000 \text { protects both } \\
\text { men and women. } \\
\text { Punishment: up to } \\
3 \text { years and/or fine } \\
\text { up to ₹2 lakh. }\end{array}$ & $\begin{array}{l}\text { Penalise the act of } \\
\text { capturing images of, } \\
\text { or watching, a } \\
\text { woman engaging in } \\
\text { sexual acts or when } \\
\text { her genitals are } \\
\text { exposed with } \\
\text { imprisonment for } 1 \\
\text { to } 3 \text { years and fine. }\end{array}$ & $\begin{array}{l}\text { Specific offence. Only } \\
\text { protects women. 1st } \\
\text { offence punishable with } \\
1 \text { to } 3 \text { years } \\
\text { imprisonment and fine. } \\
\text { 2nd offence punishable } \\
\text { with } 3 \text { to } 7 \text { years. }\end{array}$ \\
\hline Other forms of rape & $\begin{array}{l}\text { Rape includes un- } \\
\text { consented } \\
\text { penetration of the } \\
\text { mouth, anus, urethra } \\
\text { or vagina with the } \\
\text { penis or other object; } \\
\text { un-consented oral } \\
\text { sex. }\end{array}$ & $\begin{array}{l}\text { In the absence of } \\
\text { penile-vaginal } \\
\text { penetration } \\
\text { offence } \\
\text { outraging modesty } \\
\text { of a woman } \\
\text { punishable with } \\
\text { maximum } 2 \text { years } \\
\text { and fine, IPC, } 1860\end{array}$ & & $\begin{array}{l}\text { Specific offence. } \\
\text { Punishable with } 7 \text { years } \\
\text { to life imprisonment } \\
\text { (rigorous } \\
\text { imprisonment). }\end{array}$ \\
\hline Marital rape & $\begin{array}{l}\text { Forceful sexual acts } \\
\text { committed without } \\
\text { the consent of the } \\
\text { partner. }\end{array}$ & & $\begin{array}{l}\text { Should be an offence } \\
\text { regardless of the age } \\
\text { of the wife. }\end{array}$ & $\begin{array}{l}\text { Is not an offence if the } \\
\text { wife is over } 16 \text { years of } \\
\text { age. }\end{array}$ \\
\hline $\begin{array}{l}\text { Forcibly showing } \\
\text { pornography }\end{array}$ & $\begin{array}{l}\text { Forcibly showing } \\
\text { pornography by a } \\
\text { man to a woman. }\end{array}$ & $\begin{array}{lr}\text { No } & \text { specific } \\
\text { provision, } & \text { IPC, } \\
1860 & \end{array}$ & & $\begin{array}{l}\text { Punishable } r \text { with } \\
\text { rigorous imprisonment } \\
\text { for up to } 3 \text { years } \\
\text { imprisonment and/or } \\
\text { fine. }\end{array}$ \\
\hline $\begin{array}{l}\text { Protection against } \\
\text { disclosure of } \\
\text { identity of victim }\end{array}$ & & $\begin{array}{l}\text { Provided in case of } \\
\text { rape, custodial } \\
\text { rape, rape of a } \\
\text { judicially separated } \\
\text { wife, abuse of } \\
\text { power to obtain } \\
\text { consent. } \\
\text { Punishable with } \\
\text { imprisonment for } \\
\text { up to } 2 \text { years, CCP, } \\
1973\end{array}$ & & $\begin{array}{l}\text { Protection extended to } \\
\text { victims of repeat } \\
\text { offenders as well. }\end{array}$ \\
\hline $\begin{array}{l}\text { Identification of } \\
\text { accused }\end{array}$ & & $\begin{array}{lr}\text { No } & \text { specific } \\
\text { provision } & \text { for } \\
\text { special } & \text { procedures } \\
\text { to } & \text { assist }\end{array}$ & & $\begin{array}{lr}\text { Judicial magistrate to } \\
\text { undertake } & \text { special } \\
\text { procedures to assist } \\
\text { differently } & \text { abled }\end{array}$ \\
\hline
\end{tabular}




\begin{tabular}{|c|c|c|}
\hline & $\begin{array}{lr}\text { differentially } & \text { abled } \\
\text { persons } & \text { in } \\
\text { identification } & \text { of } \\
\text { accused, } & \text { CCP, } \\
1973 . & \\
\end{array}$ & $\begin{array}{l}\text { persons in identification } \\
\text { of the accused. } \\
\text { Identification process to } \\
\text { be video graphed. }\end{array}$ \\
\hline $\begin{array}{ll}\text { Recording } & \text { of } \\
\text { information } & \text { by } \\
\text { woman officer } & \end{array}$ & $\begin{array}{l}\text { No special } \\
\text { requirement for } \\
\text { woman officers to } \\
\text { record information } \\
\text { about sexual } \\
\text { offence cases, CCP, } \\
1973\end{array}$ & $\begin{array}{l}\text { In case of acid attack, } \\
\text { sexual harassment, } \\
\text { disrobing, voyeurism, } \\
\text { outraging a woman's } \\
\text { modesty, rape (of all } \\
\text { kinds) information } \\
\text { would be recorded by } \\
\text { woman officer. }\end{array}$ \\
\hline $\begin{array}{l}\text { Recording of } \\
\text { information in case } \\
\text { victim is } \\
\text { physically/mentally } \\
\text { disabled }\end{array}$ & $\begin{array}{l}\text { No } \quad \text { special } \\
\text { requirement, CCP, } \\
1973\end{array}$ & $\begin{array}{l}\text { In case of VAW like } \\
\text { acid attack, sexual } \\
\text { harassment, disrobing, } \\
\text { voyeurism, outraging a } \\
\text { woman's modesty, } \\
\text { rape information } \\
\text { would be recorded by } \\
\text { woman officer at a } \\
\text { place of the victim's } \\
\text { choice, in the presence } \\
\text { of special educators. } \\
\text { Required to be video } \\
\text { graphed. }\end{array}$ \\
\hline $\begin{array}{l}\text { Exception to } \\
\text { police's power to } \\
\text { require attendance } \\
\text { by witnesses }\end{array}$ & $\begin{array}{l}\text { Men below } 15 \\
\text { years of age and } \\
\text { women are not } \\
\text { required to give } \\
\text { evidence at a } \\
\text { police station. } \\
\text { Evidence to be } \\
\text { taken from home, } \\
\text { CCP, } 1973\end{array}$ & $\begin{array}{l}\text { Applies to men below } \\
15 \text { or above } 65 \text { years of } \\
\text { age; women and } \\
\text { physically and mentally } \\
\text { disabled persons. }\end{array}$ \\
\hline $\begin{array}{l}\text { Judicial Magistrate } \\
\text { to record } \\
\text { statement }\end{array}$ & $\begin{array}{l}\text { No special } \\
\text { requirement in } \\
\text { case of sexual } \\
\text { offences, CCP, } \\
1973\end{array}$ & $\begin{array}{l}\text { Judicial Magistrate to } \\
\text { record statement of the } \\
\text { victim immediately } \\
\text { after the police is } \\
\text { informed in case of acid } \\
\text { attack, rape, sexual } \\
\text { harassment, disrobing, } \\
\text { voyeurism etc. In case } \\
\text { the victim is differently } \\
\text { abled, the assistance of } \\
\text { interpreters has to be } \\
\text { taken and has to be } \\
\text { video graphed. }\end{array}$ \\
\hline $\begin{array}{l}\text { Examination of } \\
\text { victim at trial stage }\end{array}$ & $\begin{array}{l}\text { No special } \\
\text { protections to } \\
\text { victims of sexual } \\
\text { offences, CCP, } \\
1973\end{array}$ & $\begin{array}{l}\text { The statement } \\
\text { recorded by the } \\
\text { Judicial Magistrate will } \\
\text { be treated as the } \\
\text { evidence of the victim } \\
\text { presented by the } \\
\text { prosecutor. Protects } \\
\text { the right to be cross- } \\
\text { examined. }\end{array}$ \\
\hline
\end{tabular}


Bhattacharyya. Space and Culture, India 2013, 1:1

\begin{tabular}{|c|c|c|}
\hline $\begin{array}{l}\text { Protection against } \\
\text { confrontation of } \\
\text { victim by accused }\end{array}$ & $\begin{array}{l}\text { No special } \\
\text { protections to } \\
\text { victims of sexual } \\
\text { offences, CCP, } \\
1973\end{array}$ & $\begin{array}{l}\text { In case the victim of } \\
\text { rape or a sexual } \\
\text { offence is less than } 18 \\
\text { years of age care has } \\
\text { to be taken that she is } \\
\text { not confronted by the } \\
\text { accused. }\end{array}$ \\
\hline $\begin{array}{l}\text { Requirement of } \\
\text { sanction } \\
\text { prosecute public } \\
\text { servant }\end{array}$ & $\begin{array}{l}\text { Sanction is } \\
\text { required } \\
\text { prosecute public } \\
\text { servants in all } \\
\text { cases, including } \\
\text { cases of rape, } \\
\text { outraging } \\
\text { woman's } \\
\text { modesty, CCP, } \\
1973\end{array}$ & $\begin{array}{l}\text { Requirement of } \\
\text { sanction removed } \\
\text { under the CCP, } 1973 . \\
\text { Such requirement may } \\
\text { continue under other } \\
\text { laws. }\end{array}$ \\
\hline $\begin{array}{l}\text { Requirement of } \\
\text { satisfaction of } \\
\text { prima facie facts in } \\
\text { case of rape }\end{array}$ & $\begin{array}{l}\text { No such } \\
\text { requirement, CCP, } \\
1973\end{array}$ & $\begin{array}{l}\text { In case of rape of a } \\
\text { judicially separated } \\
\text { wife by her husband, } \\
\text { the court has to be } \\
\text { prima facie satisfied of } \\
\text { the facts constituting } \\
\text { the offence before it } \\
\text { takes cognizance. }\end{array}$ \\
\hline $\begin{array}{l}\text { Requirement to } \\
\text { fast track }\end{array}$ & $\begin{array}{l}\text { No requirement } \\
\text { to fast track } \\
\text { sexual offence } \\
\text { cases, CCP, } 1973\end{array}$ & $\begin{array}{l}\text { Trial to be held on day- } \\
\text { to-day basis. In case of } \\
\text { rape cases, trial to be } \\
\text { completed in } 2 \text { months } \\
\text { of filing of charge } \\
\text { sheet. }\end{array}$ \\
\hline Compensation & $\begin{array}{l}\text { The State } \\
\text { government has } \\
\text { to prepare a } \\
\text { compensation } \\
\text { scheme for } \\
\text { rehabilitation of } \\
\text { victims. The state } \\
\text { or district legal } \\
\text { service authority } \\
\text { is to make } \\
\text { compensation } \\
\text { awards, CCP, } \\
1973\end{array}$ & $\begin{array}{l}\text { Compensation } \\
\text { awarded by the State } \\
\text { is in addition to what } \\
\text { is payable by the } \\
\text { accused. }\end{array}$ \\
\hline $\begin{array}{l}\text { Previous sexual } \\
\text { history }\end{array}$ & $\begin{array}{l}\text { No specific } \\
\text { provision barring } \\
\text { the use of } \\
\text { previous sexual } \\
\text { history in rape } \\
\text { cases, IEA, } 1872\end{array}$ & $\begin{array}{l}\text { Bars the use of past } \\
\text { sexual history in } \\
\text { determining consent } \\
\text { of the victim. Bars } \\
\text { evidence or questions } \\
\text { in the cross- } \\
\text { examination of the } \\
\text { victim as to the } \\
\text { general immoral } \\
\text { character of the victim } \\
\text { or past sexual history } \\
\text { with any person. }\end{array}$ \\
\hline $\begin{array}{l}\text { Presumption of } \\
\text { consent }\end{array}$ & $\begin{array}{l}\text { Required the } \\
\text { victim of rape to }\end{array}$ & $\begin{array}{l}\text { Shifts the onus on to } \\
\text { the accused to prove }\end{array}$ \\
\hline
\end{tabular}




\begin{tabular}{|c|c|c|}
\hline & $\begin{array}{l}\text { prove that she did } \\
\text { not consent, IEA, } \\
1872\end{array}$ & $\begin{array}{l}\text { that consent was } \\
\text { given. }\end{array}$ \\
\hline $\begin{array}{l}\text { Special provisions } \\
\text { for evidence by } \\
\text { differently abled } \\
\text { persons }\end{array}$ & $\begin{array}{lr}\text { No } & \text { special } \\
\text { provision, } & \text { IEA, } \\
1872 & \end{array}$ & $\begin{array}{l}\text { Court to use the } \\
\text { assistance of } \\
\text { interpreters to take } \\
\text { evidence of differently } \\
\text { abled persons. Such } \\
\text { evidence to be } \\
\text { considered } \\
\text { evidence when given in } \\
\text { open court. Statement } \\
\text { to be video recorded. }\end{array}$ \\
\hline $\begin{array}{l}\text { Punishment for } \\
\text { rape }\end{array}$ & $\begin{array}{l}7 \text { years to life } \\
\text { imprisonment } \\
\text { and fine, PCSO, } \\
2012\end{array}$ & $\begin{array}{l}10 \text { years to life } \\
\text { imprisonment and } \\
\text { fine. }\end{array}$ \\
\hline Gang rape of child & $\begin{array}{l}10 \text { years to life } \\
\text { imprisonment } \\
\text { and fine, PCSO, } \\
2012\end{array}$ & $\begin{array}{l}20 \text { years to life } \\
\text { imprisonment and } \\
\text { fine. }\end{array}$ \\
\hline Disrobing & $\begin{array}{l}3 \text { years and fine, } \\
\text { PCSO, } 2012\end{array}$ & $\begin{array}{lrr}3 \quad \text { to } \quad 7 & \text { years } \\
\text { imprisonment } & \text { and } \\
\text { fine. } & & \\
\end{array}$ \\
\hline
\end{tabular}

Sources: Verma, J.S., Seth, L., and Subramanium, M. (2013, January, 23) Report of the Committee on Amendments to Criminal Law; The Criminal Law (Amendment) Bill, 2013, Bill no. 63-c of 2013, as passed by Lok Sabha on March 21, 2013; Kalra, H. (2013 March, 23) Comparison between the Criminal Laws Amendment Bill, 2013 and existing laws with regard to change in punishment for various offences, PRS Legislative Research, Institute for Policy Research Studies, New Delhi; Kalra, H. (2013 March, 23) Amendments to laws other than the IPC brought about by the Criminal Laws Amendment Bill, 2013, PRS Legislative Research, Institute for Policy Research Studies, New Delhi; Kalra, H. (2013 February, 06)Comparison between the Criminal Law (Amendment) Bill, 2012; the Report of the Committee on Amendment to Criminal Laws; and the Criminal Law (Amendment) Ordinance, 2013, PRS Legislative Research, Institute for Policy Research Studies, New Delhi; Kalra, H. (2013 March, 23)New offences under the Criminal Law Amendment Bill, 2013, PRS Legislative Research, Institute for Policy Research Studies, New Delhi

\section{Violence against Women}

Subtle analyses of the type of offences (Table 1) specifically related to women as a 'category', reinforced by the VAW statistics, National Crime Records Bureau (NCRB), Ministry of Home affairs, GOI unfold that gender biases remain deeply in-grained in society, sustained by the institutions of patriarchy. NCRB (2011) recorded a total of 228650 incidents of VAW [42968 (18.79\%)-molestation, 8570 (3.75\%) sexual harassment, 24206 (10.58\%) -rape, 35565 - kidnapping and abduction, 8618-dowry deaths and 99135 (43.35\%)-cruelty by husband and relatives]. Appalling statistics unpack that from $1953-2011$, rape rose by $873 \%$, which is three times faster, when all VAW put together (Bidwai, 2012). Shockingly, a woman is raped every 22 minutes; every 58 minutes a daughterin-law burnt for dowry and every 51 minutes a woman faces harassment in the public spaces of India. Ironically, NCRB (2011) also unfolds that 7112 cases of rape were committed against children, where one in three of the total rape victims is a child. That said, Bidwai (2012: 6 ) argues that the key reason, which galvanise VAW in public spaces is the "sexual frustration and machismo." This is further augmented by the July 09, 2012 Guwahati molestation ${ }^{4}$ case followed by Nirbhaya and similar other incidents that continue to be reported.

Anglo-American scholar, MacKinnon (1979) argues that harassment is as an exertion of power to influence the broad-scale system of male-domination and hetero-sexual nature of

\footnotetext{
${ }^{4} 11$ convicted, four acquitted in Guwahati molestation case (2012, December 07), The Hindu, http://www.thehindu.com/news/national/otherstates/11-convicted-four-acquitted-in-guwahatimolestation-case/article4174500.ece (accessed April 07, 2013)
} 
the society (here, Indian society), which manifests subordination of 'women as a class' in general and structural subordination of women (Kabeer, 2013) in particular. For instances, perpetration of harassment by upper class/caste men over women of lower class/castes; by the police, who often demean a woman complainant and harass the complainant by quizzing vulgar details; by the armed forces, who use VAW (particularly rape) as 'a weapon of war' especially in the conflict ravaged zones of India: North East India, Kashmir, Jharkhand to annihilate the community in general and progeny of the family in particular (Kabeer, 2013), thereby, gain control by paralysing the entire sociopolitical process.

Dreadfully, according to a study conducted by UNICEF $(2012)^{5}$ reveals that $57 \%$ Indian boys aged 15-19 years justify wife-battering. In a similar study by the Thomson Reuters Foundation, ${ }^{6}$ unfold that $52 \%$ of Indian women themselves accept some form of domestic violence by men against women. Such staggering revelations echoes that gender remains stratified in neoliberal modern India. These underlying attitudes, which ignite widening gender inequalities, are perhaps far more frightening and worrying with profound consequences, when it comes to the everyday practices of an individual and or groups. What is more surprising and shameful is that in case of VAW, it is the 'victim' who is blamed in our society rather than the perpetrator (Lahiri and Bandyopadhyay, 2012). In the said context, though unsurprising, the misogynistic rants made by some of the members of Parliament/State legislatures, spiritual gurus in relation to the Nirbhaya case unmask an

\footnotetext{
${ }^{5}$ Progress for Children: A report card on adolescents, Number 10, April 2012, available at:

http://www.unicef.org/media/files/PFC2012_A_report_c ard_on_adolescents.pdf (accessed February 28, 2013)

${ }^{6}$ Canada best $\mathrm{G} 20$ country to be a woman (2012,

June13). India worst - Trust Law poll, A Thomson Reuters Foundation Service,

http://www.trust.org/trustlaw/news/poll-canada-bestg20-country-to-be-a-woman-india-worst/ (accessed September 05, 2012).
}

inherent gender inequality in the attribution of intent. Some of the voices of misogyny on how women invite rape upon themselves are:

- "Only 5-6 people are not the culprits. The victim is as guilty as her rapists... She should have called the culprits brothers and begged before them to stop... This could have saved her dignity and life. Can one hand clap? I don't think so,"

- "Such crimes (rapes) hardly take place in 'Bharat', but they occur frequently in 'India'."

- "We have told the chief minister in the assembly that the government will pay money to compensate rape victims. What is your fee? If you are raped, what will be your fee?"

- "Jab tak koi mahila tedhi nazar se hasegi nahi tab tak koi aadmi usse chhedega nahi (No man will harass a woman unless led on by her)".

The list of such statements continues unabated. Unarguably, the deep-rooted prejudices that extend to women in general and the pervasive VAW in public spaces have often restricted women's mobility.

Scholars argue that most Indian women maintain a delusion of safety barrier by drawing on boundaries to their bodies and personal spaces through the practices of Indian femininity while accessing and negotiating public spaces (Phadke, 2005; 2007; Phadke et al., 2011) as the onus of remaining safe lies squarely on the women. Arguably, such restrictive approaches reflect that women remain vulnerable in accessing public spaces.

\section{Will the Act enhance women's safety?}

Access to violence free and safe public space is the basic right of a woman. Yet, the greatest challenge relates to the alarming threat to women's safety and freedom of movement in public spaces. Notwithstanding the Act (please refer to Table 1) advocates its focus on VAW and seeks to provide stringent punishment to the perpetrators of extreme cases of rapes and gang rapes. However, the question arises will 
'Ionger jail terms' or 'capital punishment' enhance women's safety and security in public, although for sure such law may inculcate a sense of fear among the culprits.

For the first time, the Act endeavours punishable offence for those police officers who fail to register First Information Report (FIR). The Act also addresses penalties for other abhorrent forms of crime (stalking, touching, sexually coloured remarks, voyeurism, human trafficking and acid attacks, awarding a minimum 10-year jail term to the perpetrators and reasonable fine to meet the medical expenses of the victim). However, it remains unclear as to how the perpetrators of the offences like touching, stalking, and sexually coloured remarks would be accused and subsequently prove the assailant as guilty.

Although, there is no comprehensive statistics on the number of acid attacks, a study conducted by Cornell University (2011) reports that in between January 2002-October 2010, 153 cases of acid attacks were reported, which not only disfigured the victims, but also ruined and isolated their lives. Disgracefully, a bottle of hazardous chemical is easily available in the informal market, which is relatively cheap (₹50), but sufficient to disfigure a woman. However, the GOI is yet to enforce strict regulation of production, storage, distribution and sale of these concentrated chemicals. At the same time, the Act fails to frame legislation that eliminates easy access to acid, though Tamil Nadu has already introduced a legislation to control its sale.

In addition, the Act also fails to address contentious issues like 'marital rape' or 'legal immunity' for army officials. The JVC report suggests that any army official accused of sexual assault or rape should be tried under civilian law and should not be protected by the law that guarantees absolute protection. Although, the Act considers 'rape by armed personnel' within the area they are posted in as an offence, with punishment of no less than seven years, and which may extend to imprisonment for life and fine, however, this offence is meaningless for the military officers /soldiers deployed in the states of North East India, Jharkhand and Jammu and Kashmir, where the 1958 draconian Armed Forces Special Powers Act (AFSPA) is still in force, which guarantees effective immunity to the armed officials. This means that not only those victims of brazen rapes, murders and other brutal sexual violence by the armed officers where the AFSPA functions may fail to seek justice, ${ }^{7,8}$ but also the perpetrators of these heinous VAW may never face prosecution; however, they may be awarded gallantry. It is worth noting here that AFSPA continues to operate despite the continuous silent opposition by Irom Sharmila, the Iron Lady of Manipur, who has been on the world's longest hunger strike, since November 02, 2000 demanding GOI to repeal AFSPA.

Further, the Act has increased the age of consent to 18 years, which remained 16 since 1983.Critics argue that raising the age of consent to 18 leaves ample room to wrongly prosecute teenagers (boys) below 18 (more precisely 16-18) years as rapists or offenders of sexual assaults simply for kissing, hugging or even having consensual sex with a female counterpart of his age (Krishnan, 2013).

Hence, the Act falls short off what many feminist organisations seeks for, and therefore, criticises the Act as 'tokenism'.

\footnotetext{
${ }^{7}$ Thangjam Manorama, who was picked up in 2004 by 17 Assam Rifles from her home on suspicion of being militant was raped and then murdered, 2004 Manorama Devi rape-murder: No action against armed forces yet (2013, January15), CNN-IBN India,

http://ibnlive.in.com/news/2004-manorama-devirapemurder-no-action-against-armed-forces-yet/3157943-225.html (accessed February 05, 2013).

${ }^{8}$ On the night of February 23 1991, in a village called Kunan-Poshpora, located in Kashmir's remote Kupwara District, at least 53 women were mass raped by Indian soldiers (Joshi, 1999). However, justice is yet to be sought to these survivors, Mass Rape Survivors Still Wait for Justice in Kashmir, TrustLaw: A Thomson Reuters Foundation Service (2012, March 07), http://www.webcitation.org/68ICeGR3T (accessed February 03, 2013)
} 


\section{What needs to be done?}

Despite its flaws, the Act bears a progressive insight to make an impact and fight a battle against VAW. However, the Act by itself is not sufficient to redress and seek justice for VAW. For this, the GOI needs to make colossal investments in building necessary infrastructure to deal with the crimes supplemented by meaningful reforms in judiciary (building fast track women's courts, more engagement of women lawyers, women doctors to examine victims) and modernisation of the police system across whole of India.

In the wake of the Nirbhaya incident, the GOI has announced a Nirbhaya fund of ₹ 10 billion in the 2013-14, Union Budget, to enhance women's safety and security in public spaces, a tribute to the brave soul. As a starting point, perhaps the Nirbhaya fund can be best utilised to conduct a safety audit in each state/union territory to redesign the architecture of its towns and cities and vis-à-vis assess the vulnerable spots that are most likely to invite upon VAW, plug these flaws and develop strategies for crime prevention.

Alongside, it remains well documented that the streetlights of most Indian cities remain inadequate and fail to function properly. The JVC report too (pp. 420) recommends, "street lighting everywhere would provide more safety since dark areas are more prone to facilitate crimes". The underlying irony is that though most cities adhere to the norms of the Ministry of Urban Development and provide street lights every 40 metres bearing a minimum illumination capacity of 35 lux, however, most of these lights (in most towns and cities)remain either dysfunctional or the level of performance remain very poor with a very low gleaming potency. ${ }^{9}$ Hence, all the states must take urgent steps to revamp and strengthen highly efficient public lighting facilities, perhaps using smarter lights. Possibly, the urban spaces of each state must initiate to install Light

\footnotetext{
${ }^{9}$ On the bright side (2013, April 19), The Hindu, http://www.thehindu.com/opinion/editorial/on-thebright-side/article4634186.ece (accessed April 19, 2013)
}

Emitting Diode (LED) lamps, which are deemed as highly efficient having 50,000 hours of life. It is evident that although initial installation of these lamps involves higher capital costs, but being highly energy efficient, it would entail higher savings in terms of its operations and maintenances. This will definitely spur the safety and security of the urban spaces and boost public confidence.

A 2012 study conducted by the Bureau of Police Research \& Development (BPR\&D) reveals shortage of manpower in the police departments (Table 2). For every 568 persons, there is only one policeman and the ratio of police to population is 176.2 police per one hundred thousand of population. On a scrutiny, a minimum 88 persons are looked after by one police officer in Tripura and Manipur through to a maximum of 1,187 and 1,133 respectively in West Bengal and Bihar. The case of Nirbhaya, who was murdered in the moving bus (without permit)having black tinted windows, and which passed through successive check posts without being confronted demonstrate the case of poor policing. It is hard to imagine, when the nation's capital lacks security, what could be the conditions of other states and union territories?

Further, JVC report also unfolds that not only police are apathetic towards gender justice but also (as stated above) are insensitive in tackling VAW. Alongside, stark evidence shows that due to the very low availability of women police officers, many women victims fail to complain a sex crime (Bhattacharyya, in press): there are approximately 84,479 women (Table 2) in different police departments out of an all India total (Civil Police + Armed Police) of 2,124,596, which merely constitute $3.98 \%$ of the total police force. However, the Act requires that a female officer should record all information in the case of offences like acid attack, sexual harassment, disrobing, voyeurism, outraging a woman's modesty, rape (of all kinds). Hence, the GOI urges all states/union territories to increase the number of female police officers to $33 \%$ of the total police strength. 
Table 2 Population per Policeman, Sanctioned and Actual (2012)

\begin{tabular}{|c|c|c|c|c|c|}
\hline \multirow[t]{3}{*}{ Arunachal Pradesh } & PP (SPS) & 109 & \multirow[t]{3}{*}{ Maharashtra } & PP (SPS) & 614 \\
\hline & PP (APS) & 161 & & PP (APS) & 829 \\
\hline & ASWP & 399 & & ASWP & 20062 \\
\hline \multirow[t]{3}{*}{ Andhra Pradesh } & PP (SPS) & 642 & \multirow[t]{3}{*}{ Manipur } & PP (SPS) & 88 \\
\hline & PP (APS) & 953 & & PP (APS) & 119 \\
\hline & ASWP & 2031 & & ASWP & 636 \\
\hline \multirow[t]{3}{*}{ Assam } & PP (SPS) & 507 & \multirow[t]{3}{*}{ Meghalaya } & PP (SPS) & 207 \\
\hline & PP (APS) & 566 & & PP (APS) & 239 \\
\hline & ASWP & 620 & & ASWP & 220 \\
\hline \multirow[t]{3}{*}{ Bihar } & PP (SPS) & 1133 & \multirow[t]{3}{*}{ Mizoram } & PP (SPS) & 91 \\
\hline & PP (APS) & 1456 & & PP (APS) & 98 \\
\hline & ASWP & 1485 & & ASWP & 575 \\
\hline \multirow[t]{3}{*}{ Chhattisgarh } & PP (SPS) & 345 & \multirow[t]{3}{*}{ Nagaland } & PP (SPS) & 94 \\
\hline & PP (APS) & 525 & & PP (APS) & 94 \\
\hline & ASWP & 1931 & & ASWP & 259 \\
\hline \multirow[t]{3}{*}{ Goa } & PP (SPS) & 291 & \multirow[t]{3}{*}{ Odhisa } & PP (SPS) & 750 \\
\hline & PP (APS) & 343 & & PP (APS) & 899 \\
\hline & ASWP & 347 & & ASWP & 3675 \\
\hline \multirow[t]{3}{*}{ Gujarat } & PP (SPS) & 571 & \multirow[t]{3}{*}{ Punjab } & PP (SPS) & 348 \\
\hline & PP (APS) & 1021 & & PP (APS) & 383 \\
\hline & ASWP & 2021 & & ASWP & 2789 \\
\hline \multirow[t]{3}{*}{ Haryana } & PP (SPS) & 406 & \multirow[t]{3}{*}{ Rajasthan } & PP (SPS) & 814 \\
\hline & PP (APS) & 610 & & PP (APS) & 895 \\
\hline & ASWP & 3077 & & ASWP & 5698 \\
\hline \multirow[t]{3}{*}{ Himachal Pradesh } & PP (SPS) & 393 & \multirow[t]{3}{*}{ Sikkim } & PP (SPS) & 114 \\
\hline & PP (APS) & 460 & & PP (APS) & 157 \\
\hline & ASWP & 1420 & & ASWP & 189 \\
\hline \multirow[t]{3}{*}{ Jammu and Kashmir } & PP (SPS) & 179 & \multirow[t]{3}{*}{ Tamil Nadu } & PP (SPS) & 608 \\
\hline & PP (APS) & 192 & & PP (APS) & 713 \\
\hline & ASWP & 2185 & & ASWP & 10118 \\
\hline \multirow[t]{3}{*}{ Jharkhand } & PP (SPS) & 429 & \multirow[t]{3}{*}{ Tripura } & PP (SPS) & 88 \\
\hline & PP (APS) & 567 & & PP (APS) & 101 \\
\hline & ASWP & 1842 & & ASWP & 697 \\
\hline \multirow[t]{3}{*}{ Karnataka } & PP (SPS) & 656 & \multirow[t]{3}{*}{ Uttar Pradesh } & PP (SPS) & 52 \\
\hline & PP (APS) & 751 & & PP (APS) & 1173 \\
\hline & ASWP & 3348 & & ASWP & 2586 \\
\hline \multirow[t]{3}{*}{ Kerela } & PP (SPS) & 702 & \multirow[t]{3}{*}{ Uttarkhand } & PP (SPS) & 499 \\
\hline & PP (APS) & 765 & & PP (APS) & 638 \\
\hline & ASWP & 3001 & & ASWP & 1498 \\
\hline Madhya Pradesh & PP (SPS) & 880 & West Bengal & PP (SPS) & 1187 \\
\hline & PP (APS) & 962 & & PP (APS) & 1658 \\
\hline
\end{tabular}


Bhattacharyya. Space and Culture, India 2013, 1:1

\begin{tabular}{|c|c|c|c|c|c|}
\hline & ASWP & 3010 & & ASWP & 1811 \\
\hline \multirow[t]{3}{*}{ Andaman \&Nicobar } & PP (SPS) & 101 & \multirow[t]{3}{*}{ Delhi } & PP (SPS) & 234 \\
\hline & PP (APS) & 122 & & PP (APS) & 253 \\
\hline & ASWP & 388 & & ASWP & 5356 \\
\hline \multirow[t]{3}{*}{ Chandigarh } & PP (SPS) & 147 & \multirow[t]{3}{*}{ Lakshadweep } & PP (SPS) & 212 \\
\hline & $P P(A P S)$ & 159 & & PP (APS) & 250 \\
\hline & ASWP & 985 & & ASWP & 16 \\
\hline \multirow[t]{3}{*}{ Dadra \& Nagar Haveli } & PP (SPS) & 902 & \multirow[t]{3}{*}{ Pondicherry } & PP (SPS) & 289 \\
\hline & PP (APS) & 1046 & & PP (APS) & 433 \\
\hline & ASWP & 26 & & ASWP & 168 \\
\hline \multirow[t]{3}{*}{ Daman \& Diu } & PP (SPS) & 590 & \multirow[t]{3}{*}{ All India Total } & PP (SPS) & 568 \\
\hline & PP (APS) & 805 & & PP (APS) & 761 \\
\hline & ASWP & 10 & & ASWP & 84479 \\
\hline
\end{tabular}

Population per Policeman (Sanctioned Police Strength)=PP (SPS)

Population per Policeman (Actual Police Strength)=PP (APS)

Actual Strength of Women Police $=$ ASWP

Source: Data on Police Organisations in India as on January 1, 2012,Bureau of Police Research \& Development, New Delhi

Importantly, 'real policing' for ordinary citizens remain far lower as approximately 3 police officers are recruited for providing securities for each Very Important Person (VIP) ${ }^{10}$, which is far more than the actual sanctioned strength of police officers on this matter, though for some VIPs, the number may sometimes escalate even more. Strikingly, a good number of police officers need to be deployed at the time of a major political event or a VIP visit, which severely affects night patrolling and other crime-prevention measures. Very importantly, there remains a dire need in implementing a model of change in real policing for ordinary citizens alongside rectifying the perennial annoyances (inadequate logistics including lack of forensic facilities or specialised crime units, meagre training, and poor intelligence) necessary for making the entire police force more efficient.

Further, NCRB (2011) data unpacks that approximately $83.6 \%$ pendency of rape cases in courts across the country. The quick justice sought to the young woman of the Guwahati

\footnotetext{
${ }^{10} 3$ cops to protect each VIP, just 1 cop for 761 citizens (2012, April 02), The Times of India, http://articles.timesofindia.indiatimes.com/2012-0402/india/31274675_1_vip-security-protectees-policepersonnel (accessed March 03, 2013)
}

molestation case by the honourable Chief Judicial Magistrate's court, Guwahati is an excellent example of fast track court. In the said context, the Act requires that rape trials should be held on fast track court on a day-today basis and completed within two months of filing the charge sheets (Table 1). Hence, for the laws to be effective, the infrastructure needs to be built as quickly as possible: for without meaningful reforms in judiciary and police, the Act will remain only as a symbolic tool, no matter as to how stringent the laws are on the papers.

\section{Conclusion}

To sum up, the role of the state remains paramount in tackling VAW. Therefore, the law implementing agencies should be adequately provided strategic training to tackle any eventuality with dexterity-even if it necessitate increasing the number sufficiently. Alongside, as also suggested by the JVC report, there remains a desperate need to improve publicpolice relationship, possibly through a good will venture (perhaps training the police officials as well as the public in gender sensitive programmes). Challenge therefore, lies in scaling the mechanism of coordination and cooperation from few to all stakeholders of the state. To be more precise, the executive, who is delegated with the responsibility of 
investigating a trial in a judiciary, should bear a sense of accountability (rather than misusing its power) in ferreting out the actuality of the facts so that the outcome of the trial turns out to be unbiased, fair and flawless. At the same time, the incitement and provocation alarmingly disseminated by the media and other information agencies must be shackled appropriately in compliance to decency, morality and social order- the constitutional mandate. Last, and in line with the JVC report, reformation in curriculum right from the primary level of education has to be brought; embracing value based moral lessons; incorporating perception reforms through gender-blind programmes and creating congenial atmosphere in the domestic, social and institutional sectors.

\section{Acknowledgement}

I gratefully acknowledge the comments and support received from Professor Ramesh Chandra Barpatragohain, Department of Law, Gauhati University for reviewing this commentary.

\section{References}

Bhattacharyya, R. (in press). How safe are the public spaces of North East India. In A. Hazra (ed.) Sustaining Development in North East India, New Delhi: Routledge

Bidwai, P. (2012, July 24). Shameful Violence against Women, The Assam Tribune, (6)

Combating Acid Violence in Bangladesh, India, and Cambodia (2011), A Report by the Avon Global Center for Women and Justice at Cornell Law School, the Committee on International Human Rights of the New York City Bar Association, the Cornell Law School International Human Rights Clinic, and the Virtue Foundation, www.lawschool.cornell.edu/.../CombatingAcid-Violence-Report.pdf (accessed February 27, 2013)

Data on Police Organisations in India as on January 1, 2012, Bureau of Police Research \& Development, New Delhi

Joshi, M. (1999). The Lost Rebellion, Australia: Penguin Group

Kabeer, N. (2013, January 05). Grief and rage in India: making violence against women history?, Open Democracy, http://www.opendemocracy.net/5050/nailakabeer/grief-and-rage-in-india-making-violence-againstwomen-history (accessed January 05, 2013)

Kalra, H. (2013 March, 23) Comparison between the Criminal Laws Amendment Bill, 2013 and existing laws with regard to change in punishment for various offences, PRS Legislative Research, Institute for Policy Research Studies, New Delhi

Kalra, H. (2013 March 23). Amendments to laws other than the IPC brought about by the Criminal Laws Amendment Bill, 2013, PRS Legislative Research, Institute for Policy Research Studies, New Delhi;

Kalra, H. (2013 February 06). Comparison between the Criminal Law (Amendment) Bill, 2012; the Report of the Committee on Amendment to Criminal Laws; and the Criminal Law (Amendment) Ordinance, 2013, PRS Legislative Research, Institute for Policy Research Studies, New Delhi;

Kalra, H. (2013 March 23). New offences under the Criminal Law, PRS Legislative Research, Institute for Policy Research Studies, New Delhi

Krishnan, K. (2013, March 18). A legal tool for moral policing, Tehelka.com, http://tehelka.com/a-legal-toolfor-moral-policing/ (accessed March 18, 2013)

Lahiri, C. S. and Bandyopadhyay, S. (2012). Dressing the feminine body, Economic \& Political Weekly, XLVII(46), 20-24

MacKinnon, C. (1979). The sexual harassment of working women, New Haven: Yale University Press

National Crime Records Bureau, Ministry of Home affairs, Government Of India, http://ncrb.nic.in/ (accessed March 02, 2013)

Phadke, S. (2005). 'You can be lonely in a crowd': The production of safety in Mumbai, Indian Journal of Gender Studies, 12(1), 41-62

Phadke, S. (2007). Dangerous liaisons-Women and men: Risk and reputation in Mumbai, Economic and Political Weekly, 1510-1518

Phadke, S., Khan, S. and Ranade, S. (2011). Why loiter? Women and risk on Mumbai streets. New Delhi: Viking Penguin

Verma, J.S., Seth, L., and Subramanium, M. (2013, January 23).Report of the Committee on Amendments to Criminal Law

Viswanath, K. and Mehrotra, S.T. (2007). 'Shall we go out?' Women's safety in public spaces in Delhi, Economic and Political Weekly, 1542- 1548 